\title{
MiR-935 Promotes Clear Cell Renal Cell Carcinoma Migration and Invasion by Targeting IREB2 [Retraction]
}

Liu F, Chen Y, Chen B, Liu C, Xing J. Cancer Manag Res. 2019;11:10891-10900.

At the authors request, the Editor-in-Chief and Publisher of Cancer Management and Research wish to retract the published article.

Following a review of their article the authors found some errors had been made in Figure 4E, specifically images in panels Migration miR-935 inhibitor +/si-IREB2 + and Invasion miR-935 inhibitor +/si-IREB2 +. After carefully going through the raw data for their study the authors were unable to locate the original images for Figure 4E. The authors were also unable to locate the original images for the western blots shown in the article. Both the editor and authors determined the findings of this study could no longer be supported and agreed for the article to be retracted.

The authors wish to apologise for this error.

Our decision-making was informed by our policy on publishing ethics and integrity and the COPE guidelines on retraction.

The retracted article will remain online to maintain the scholarly record, but it will be digitally watermarked on each page as "Retracted".

\section{Publish your work in this journal}

Cancer Management and Research is an international, peer-reviewed open access journal focusing on cancer research and the optimal use of preventative and integrated treatment interventions to achieve improved outcomes, enhanced survival and quality of life for the cancer patient.
The manuscript management system is completely online and includes a very quick and fair peer-review system, which is all easy to use. Visit http://www.dovepress.com/testimonials.php to read real quotes from published authors. 